\title{
Book Design of Online-Based Islamic Education Subjects At the Universitas Nahdlatul Ulama Blitar
}

\author{
Siti Uswatun Kasanah ${ }^{(1)}$, M.Subhan Ansori ${ }^{(2)}$, Abd. Charis Fauzan ${ }^{(3)}$ \\ Universitas Nahdlatul Ulama Blitar \\ E-mail: (1)sitiuswatun@unublitar.ac.id, (2)subhanansori@unublitar.ac.id, \\ (3)abdcharis@unublitar.ac.id
}

Received: 3 July 2019; Revised: 20 September 2019; Accepted: 25 September 2019

\begin{abstract}
Abstrack
Reference books on Islamic Religious Education (PAI) courses in General Higher Education (PTU) need to be designed in line with the Industrial Revolution 4.0 era. This paper is to make a reference book for Islamic Religious Education courses in General Higher Education and to design reference books online. The focus of this research is the development of Islamic religious education reference books in online-based Public Higher Education. Using the Research and Development method developed by Dick and Carey. The data was collected from the assessment of two experts through the Expert validation sheet and 11 MKDU Lecturers through the respondent questionnaire. Data analysis uses qualitative and quantitative approaches. Data analysis that Islamic Education courses at the Blitar University of Nahdlatul Ulama need to be made references and designed online. The results showed that the reference book was appropriate to be used as a reference in Islamic Religious Education courses. This is based on material validation of 410 (very good), language and images of 401 (very good), presentation of 691 (very good), display of 252 (very good).
\end{abstract}

Keywords: Design, PAI Reference Book, Online

\section{Introduction}

The background of this research is the need for online-based Islamic education reference books at Nahdlatul Ulama University in Blitar. This can support both students and lecturers to make lectures effective in the era of the all-digital industrial revolution 4.0. The scope of the discussion includes Islamic Religious Education teaching materials delivered in one semester. While the purpose of this research study is to make a reference book for Islamic Religious Education courses in General Higher Education and to design teaching materials in online form. The development of Islamic religious education reference books by utilizing technology needs to be supported and developed to maximize the existing potential. In order to develop online-based Islamic religious education it has become a necessity for education managers in Indonesia. The title underlies the need for review and development of syllabus of Islamic religious education courses in public universities. Also adapted to the development of an era that is ncreasingly fast, easy, measurable, known as the era of the industrial revolution 4.0, even $n$ some developed countries have experienced 
technological improvements to the industrial revolution 5.0.

In line with the development of the digital era known as online, it is time for the lecture process of Islamic Religious Education (PAI) to utilize this technology. Online based learning design is not only optional, but has become a necessity. The effectiveness of learning is also influenced by how much the lecturer is able to use IT. The Industrial Revolution Era 4.0 impacted the existence of conventional approaches that have been largely abandoned and turned to computer-based learning or commonly known as online learning.

Lecturers can create and innovate in planning and developing learning models. The term online learning model, can use a computer, laptop or smartphone. Learning can be done anywhere, anytime, and in any situation. Lectures can not only be done through a face-to-face process between lecturers and students. Now, students can still learn even though the distance from the lecturers is far apart.

The development of IT is utilized as much as possible Online is used synergistically with face-to-face learning, functioned as a supporter of student lectures. This is based on he idea that pure online learning cannot be fully implemented in most universities in ndonesia. Since the 1990s the internet began to emerge social media (social media) as an online media that makes it easy for its users to communicate interfaces, participate, and share. The most popular types of social media in Indonesia, including: Facebook, Whatsapp, Youtube, Flick, Instagram, Twitter, Webblog, and LinkedIn . You can also use Zoom, Edmodo, Scologi, and Google Meet.

Reference books are very helpful for students with reference books, in addition to being supported by intrapersonal intelligence so that they can easily understand their abilities and abilities in learning (Maryati, T.; Kasanah, S.U; Maf'ula, V.Y., 2019: 306-313). slamic Religious Education needs to be designed as effectively as designing online because it will be utilized by the largest adherents in Indonesia and even in the world (Kasanah, 442019: 199-204). The concept of Islamic Religious Education in General Higher Education as mandated by the Ministry of Religion, to underlie mastery of science for students and lecturers as leaders in order to become transformative leaders (Kasanah, 2019: 25-30). Indonesia which is rich in culture and customs must create a state of harmony between and among religious communities. The differences in religion, tradition and culture of the majority of Indonesians as farmers, living in villages with various customs, tribes and cultures (Kasanah, 2019: 354-364) are something to be thankful for. The concept of amaliah in Islamic Religious Education in Indonesian society needs to be understood and analyzed so that it can be studied academically. (Ansori, M.S, et al, 2019: 14-24).

As far as researchers know, this research is different and has never been studied by other researchers. Researchers found research results that were relevant to the theme of this study, namely: 1) Design of Islamic Religious Education teaching materials with an integrativeinterconnected approach between religious studies, natural sciences, social sciences and humanities; 2) Transformation of Islamic Education Curriculum Courses in General Higher Education: From Normative-Doctrinal Paradigm Towards Historical-Contextual Paradigm.

The impact of development occurs in all fields of science, including education in universities. Urgently needed design of Islamic Religious Education (PAI) teaching materials in general tertiary institutions according to the demands of the times. Existing concepts are developed and transformed as technology continues to grow, so that they are easy to obtain, easy to learn, easy to use. Therefore, I propose the title of the research, namely the book design of Islamic Education Education Subjects at OnlineBased Public Colleges.

\section{Material and Methods}

The research instruments used expert validation sheets of 2 Islamic Religious Education experts and language experts, while questionnaire respondents were 11 PAI lecturer lecturers at Universitas Nahdlatul Ulama Blitar. The analysis 


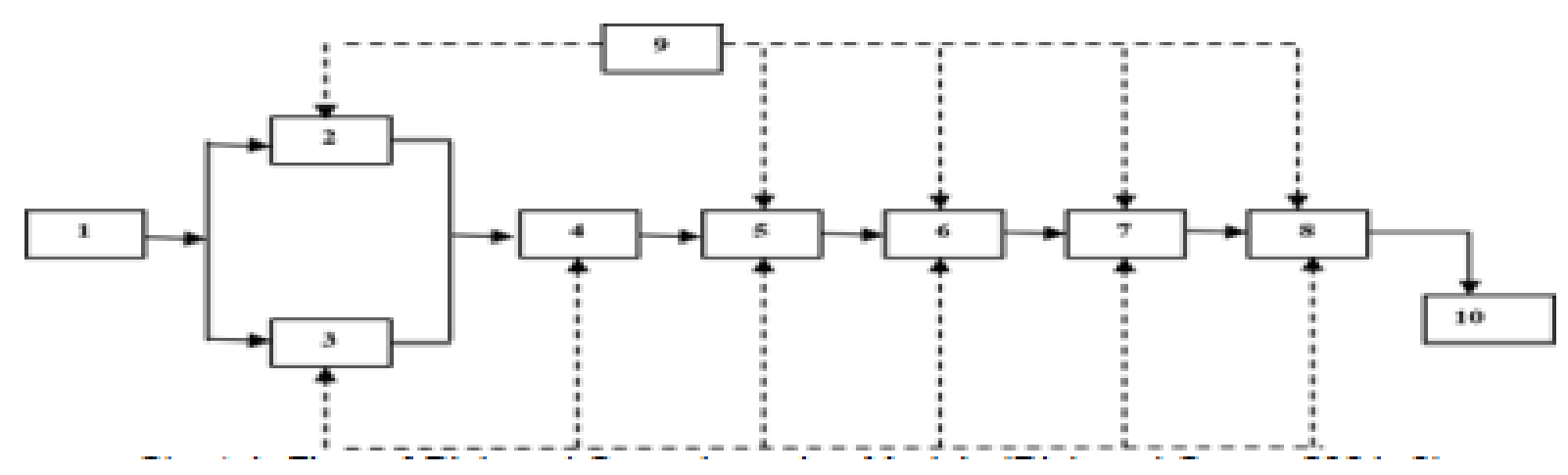

Figure 1. Flow of Dick and Carey Learning Models

used in the form of quantitative descriptive, so that the quality of reference books is known, the data in the form of quantity is converted into qualitative. While the feasibility of 44 books is known from the results of the evaluations of the student validators and questionnaires that were analyzed by validated by experts, on each sheet of book validation about the accuracy and appropriateness of learning design, material substance, and attractiveness of product presentation, the validator wrote the assessment categories using the Likert Scale assessment criteria as follows: Value 1: not good, 2: good enough, 3: good, and 4: 24 very good. The assessment is then averaged.

Data analysis techniques using qualitative and quantitative approaches. Data in the form of suggestions and criticisms from experts / experts and students were analyzed with a qualitative approach, while the data on the appropriateness of reference books and opinions regarding the suitability of the book were processed with a quantitative descriptive approach. The instrument evaluation guidelines use the guidelines proposed by Saifudin Azwar (Azwar, 442002: 163).

Table 1. Guidelines for Conversion of Average Amounts of scores into values with five categories. Source: Saifudin Azwar (2002: 163)

\begin{tabular}{|c|c|c|c|}
\hline No & Range & Rating & Category Value \\
\hline 1 & $\mathrm{Mi}+1.50 \mathrm{Sbi}<\mathrm{X}$ & A & Very Good \\
\hline 2 & $\mathrm{Mi}+0.50 \mathrm{Sb} \mathrm{C}<\mathrm{X} \leq \mathrm{Mi}+1.50 \mathrm{Sb}$ & B & Good \\
\hline 3 & Mi - $0.50 \mathrm{Sbi}<\mathrm{X} \leq \mathrm{Mi}+0.50 \mathrm{Sbi}$ & c & Good Enough \\
\hline 4 & $\mathrm{Mi}-1.50 \mathrm{Sb}$ < $<\leq \leq \mathrm{Mi}-0.50 \mathrm{Sbi}$ & D & Less \\
\hline 5 & $\mathrm{X} \leq \mathrm{Mi}-1,50 \mathrm{Sbi}$ & E & Very Poor \\
\hline
\end{tabular}

This type of research is to develop products based on trials to then be revised to produce products that are suitable for use (Sugiyono, 2011: 4-10) also validate products used in education and learning. Development model is defined as a conceptual design process for improving the function of pre-existing models that are considered to be able to improve the quality of achieving goals (Sugiarta, 2007: 11).

The development steps can be seen in the Figure 2.

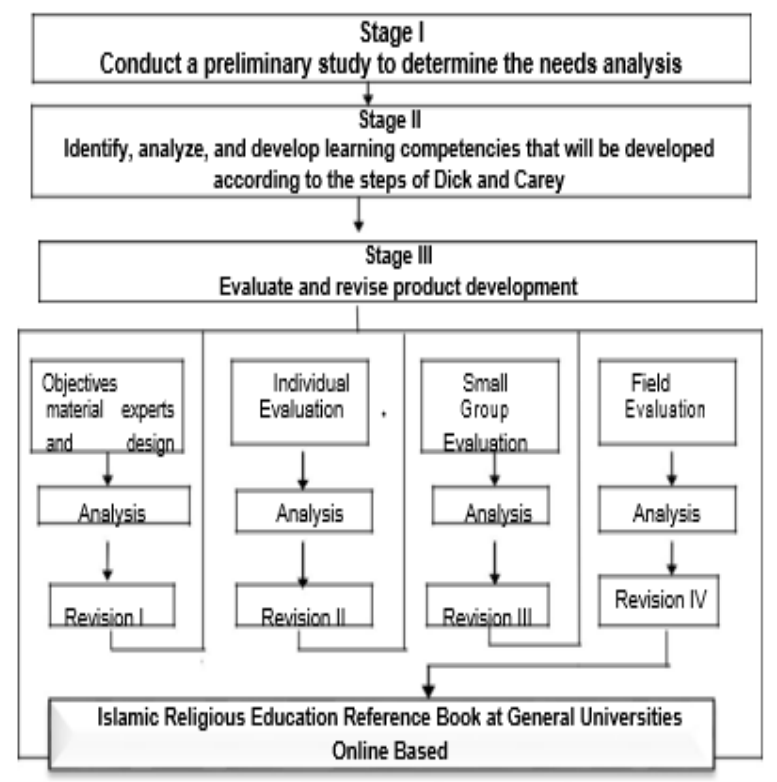

Figure 2. Chart procedure for developing a draft of the PAI Reference Book at PTU Online-based modified from the 2001 Dick and Carey model

\section{Results and Discussion}

The development procedure is based on the Dick and Carrey Model which is developed in shaping the reference book product. This development research phase was carried out until the 9th stage, namely revising the product, while the 10th stage was not carried out. In compiling a reference book for Islamic Religious Education Subjects in Onlinebased Public Colleges the steps taken are as follows: 


\section{Identify Instructional Goals (Identifying Learning Objectives)}

The first stage of identifying the general development objectives is the basis for the next step. The purpose of developing this reference book is to develop a syllabus and provide Islamic Religious Education reference books at PTU. To find out this goal, a literacy study was carried out on the curriculum as mandated by Law No.3 of 2017 concerning the book system and Regulation of the Minister of Religion No.9 of 2018 concerning the book of Religious Education. Online-based book design needs analysis through observation and interviews with PAI lecturers at the Universitas Nahdlatul Ulama Blitar as many as 11 lecturers. Student learning outcomes are able to know, understand, analyze, and apply Islamic teachings as a source of value in everyday life.

\section{Conduct Instructional Analysis (Conducting Learning Analysis)}

The analysis technique is carried out by: (1) classifying the formulation by taking into account the guidelines of Law No. 3 of 2017 and the Minister of Religion Regulation No. 9 of 2018 in several book sections and (2) formulating in 4 chapters and presenting their online form. Online learning used is Schology, Google Meeting and Edmodo.

\section{Identify Entry Behaviors (Identifying Student Characteristics)}

Researchers to identify the behavior and characteristics of students, lecturers and public figures in general as potential users of this book. in general requires books that include lecture material along with the demands of the times and curriculum policies as mandated by the government. This has led to the development of online book forms and ways of learning. The desire to learn that can penetrate boundaries and time with adequate quality becomes the needs of learners in the millennial era.

\section{Write Performance Objectives (Formulate Specific Objectives)}

The results of the analysis of learning as well as statements of initial behavior of students, then formulated what students will do. Formulation of specific objectives for achieving competencies expected after the learning process is carried out.

\section{Develop Criterion Referenced Tests (Develop Test Items)}

In accordance with the competency achievement indicators that have been formulated, then developed test items. The test was developed to train book users in learning and teaching. The number of test questions is arranged as many as 5 questions per chapter so as a whole as many as 65 questions. The question can be used by book users conducting tests as needed.

\section{Develop Instructional Strategy (Develop Learning Strategies)}

The learning strategies described by Dick and Carey are (1) pre-learning activties, (2) presentation of material or content, (3) student participation, (4) assessment, and (5) follow-up activities (Dick and 1Carey, 2001: 189). Researchers only develop the second component, namely the presentation of material or content and presentation of assessment materials or test questions.

Develop And Select Instructional Materials (Developing and Selecting Teaching Materials)

The development carried out in this study is a reference book on Islamic education courses in online-based Public Higher Education. The draft book of the product has been tested by classifying the material in five parts and consists of several chapters as follows:

First Part: God and Religion

CHAPTER I. God and Spirituality and CHAPTER II. Religion and Religiosity

Second Part: Al-Qur'an, As-Sunnah and Ijtihad

CHAPTER I: Al-Qur'an as Inspiration of Civilization in Indonesia

CHAPTER II: Sunnah as an example and Cultural Inspiration

CHAPTER III: Ijtihad and the Sustainability of Islamic Spirit

Part Three: Islamic Solutions to SocioCultural Problems and the environment

CHAPTER I: Islamic Morals in the Development of Culture, Science and Art 
CHAPTER II: Developing Muslim Work Ethics

CHAPTER III: Religion and Life Harmony

CHAPTER IV: Natural Environment as God's Gift

Part Four: Muslim Ijtihad on Politics, Islamic Moderation, Women and AntoCorruption Culture

CHAPTER I: Government and the State in Multi Perspective Ulama

CHAPTER II: Moderation of Islam to Prevent Religious Radicalism

CHAPTER III: Islam Dignifies Women

CHAPTER IV: The Role of Religion in Developing an Anti-Corruption Culture

Part Five: Online Learning

CHAPTER I: Google Classroom Based

Online Implementation

CHAPTER II: Edmodo-Based Online Implementation

CHAPTER III: Schoology Based Online

Implementation

\section{Design and Conduct Formative Evalua- tion (Designing and Conducting Forma- tive Evaluations)}

Formative evaluation aims to collect data related to the strengths and weaknesses of the draft reference book, which will then be used as input to improve the reference book. At this stage the researcher conducted an evaluation with the experts or experts and lecturers supporting the PAI course at the Universitas Nahdlatul Ulama Blitar. Evaluations conducted are:

1. expert review and design developed were carried out by material experts (Dr. Dimyati Huda, M.Ag) is an expert lecturer in Islamic Education by adding the sub theme "E" with "The Indonesian Ijtihad Ala Model". While the linguist (Melinda Fatmawati, M.Pd) of Indonesian Language Education suggested changing the cover to be more in line.

2. The results of extensive trials, the Material test obtained a score of 410 which is in the range of scores $\mathrm{X}>344$ with a very good category Index (93\%), the feasibility of the language and image fields obtained a score of 401 which is in the range of scores $\mathrm{X}>352$ with very good category Index $(91 \%)$, the feasibility of the presentation field obtained a score of 691 which was in the range of scores $X>616$ with a very good category Index $(90 \%)$ while the feasibility of the display field obtained a score of 253 which was in the range of the score $\mathrm{X}>220$ with a very Good Index $(92 \%)$ so it is feasible to be used as a reference book.

\section{Revise instructional (Revise Learning)}

The final stage of developing a reference book is to revise the draft PAI book at an onlinebased PTU. The revised material obtained from formative evaluation data was then interpreted to determine the weakness of the draft. This type of formative evaluation can be applied to develop a draft of a PAI course reference book at PTU online-based by refitting according to recommendations or suggestions from experts and lecturers. The results of the revision as mentioned above make the book more feasible for lecturers, students and the wider community to use.

\section{Conclusion}

Based on the results of research and discussion, it can be concluded that a reference book can be drawn up on Islamic Religious Education courses in General Higher Education which are highly needed for lecturers, students and public figures in general.

Islamic Religious Education reference books in Higher Education are designed as online reference books. The form of online learning is clarified with Google Classroom, edmodo and Schoology-based Online implementation instructions.

\section{References}

Ansori, M.S. dkk (2019). Meningkatkan Pem ahaman dan Ketrampilan Ibadah Haji bagPeserta Didik, Guru dan Wali Murid melalui Pembelajaran Praktek Manasik Haji untuk Anak Usia Dini. JPPNu: Jurnal Pengabdian dan Pemberdayaan Nusantara.

Azwar, S. (2002). Penyusunan skala psikolo gi. Yogyakarta: Penerbit Pustaka Pela jar.

Buana, V.G.\& Kasanah, S.U. (2019) Pengembangan Model Pembelajaran Berbasis Permainan Engklek Kelas IV Sekolah Dasar.PINUS: Jurnal Penelitian Inovasi Pembelajaran. 4(2).

Kasanah, S. U. (2018). Upaya Mewujudkan Desa Open Defecation Free di Desa Pojok Kecamatan Garum Kabupaten Blitar. Briliant: Jurnal Riset dan Konseptual 3 (3).

Kasanah, S. U. (2019). Pengantar Islam Nusan- 
tara:Konsep, Filosofi dan Aksi (Yogyakarta: Pustaka Ilmu)

Kasanah, S.U. (2019). Intersection of Leadership: Transformational, Visionary and Situational. Journal of Development Research. 3 (1).

Maryati, T. dkk. (2019).Kontribusi Kecerdasan Intrapersonal Siswa Terhadap Kesadaran Metakognitif Siswa SMK se-Kota Blitar, Briliant: Jurnal Riset dan Konseptual, 4 (3).

Sugiarta,N.S. (2017), Pengembangan Model Pengelolaan Program Pembelajaran Kolaboratif untuk Kemandirian Anak Jalanan di Rumah Singgah. Disertasi. Bandung:SPS UPI.

Sugiono, (2012). Metode Penelitian Kuantitatif, kualitatif, dan R\&D. Bandung: Alfabeta. 